\title{
Perawatan Maloklusi Kelas I Bimaksiler Protrusi disertai Gigi Berdesakan dan Pergeseran Midline menggunakan Teknik Begg
}

\author{
Erna Rahmawati* dan Soekarsono Hardjono** \\ *Program Studi Ortodonsia PPDGS Fakultas Kedokteran Gigi Universitas Gadjah Mada \\ **Bagian Ortodonsia, Fakultas Kedokteran Gigi Universitas Gadjah Mada \\ *JI Denta no 1 Sekip Utara Yogyakarta;, e-mail: erna_rahmawati1702@yahoo.com
}

\begin{abstract}
ABSTRAK
Maloklusi Angle kelas I dengan bimaksiler protrusi merupakan maloklusi yang paling sering dijumpai. Kelainan yang banyak menyertai maloklusi kelas I bimaksiler protrusi adalah gigi depan berdesakan dan pergeseran midline. Adanya persepsi negatif di masyarakat terhadap gigi dan bibir yang protrusi mendorong pasien untuk melakukan perawatan ortodontik. Perawatan pada kasus ini bertujuan untuk mengurangi kecembungan wajah dengan meretraksi gigi anterior atas maupun bawah, mengoreksi midline rahang atas dan bawah serta gigi berdesakan anterior dengan perawatan ortodontik teknik Begg sehingga dapat memperbaiki estetik wajah. Pasien wanita usia 34 tahun mengeluhkan gigi depan atas dan bawah sangat berdesakan dan pasien mengalami kesulitan dalam menutup mulut. Diagnosis pasien adalah Maloklusi Angle kelas I dengan bimaksiler protrusi disertai gigi berdesakan anterior, pergeseran midline rahang atas dan rahang bawah. Pasien dirawat menggunakan alat cekat teknik Begg. Sebelum perawatan dilakukan pencabutan gigi premolar pertama rahang bawah kanan dan kiri dan rahang atas kanan. Pada rahang atas kiri dilakukan pencabutan gigi insisivus lateral yang berada diluar lengkung. Kesimpulan perawatan setelah 2 tahun terlihat bimaksiler protrusi, gigi berdesakan anterior dan midline terkoreksi.

Maj Ked Gi; Desember 2013; 20(2): 224-230.
\end{abstract}

Kata kunci: kelas I Angle, bimaksiler protrusi, midline, gigi berdesakan, teknik Begg

ABSTRACT: Treatment for Class I Malocclusion with Bimaxillary Protrusion Accompanied by Crowding and Midshift Using Begg Technique. Angle class i malocclusion with bimaxillary protrusion Is the most common malocclusion. Abnormalities that commonly accompany class I malocclusion of bimaxillary protrusion are anterior crowding and median line shifting. Negative perceptions in the community toward teeth and lips protrusion encourage patients to perform orthodontic treatment. The aim of this case is to reduce facial convexity by retracting upper and lower anterior teeth, correcting median line on maxillary and mandibular and anterior crowded by using the Begg orthodontic technique in order to improve the facial aesthetics. A 34 year-old female patient complained about her upper and lower anterior teeth, severe crowding, and difficulty in closing her mouth. The patient was diagnosed to suffer from Angle class I malocclusion with bimaxillary protrusion and anterior crowding, median line shifting of maxillary and mandibular. Patient has been treated with the fixed appliance with Begg technique. The right and left mandibular, first premolar and the right maxillary first premolar had been extracted before treatment. On the left maxillary, lateral incisor tooth which is outside the dental arch was extracted. After 2 years of treatment, it is concluded that bimaxillary protrusion, anterior crowding and median line shifting can successfully be corrected.

Maj Ked Gi; Desember 2013; 20(2): 224-230.

Keywords: Angle class I, bimaxillary protrusion, median line, crowded teeth, the Begg technique

\section{PENDAHULUAN}

Bimaksiler protrusi merupakan salah satu maloklusi yang mempengaruhi penampilan seseorang. Karakteristik malposisi ini ditandai dengan gigi-gigi insisivus atas dan bawah protrusi serta profil yang cembung. 'Perawatan ortodontik pada bimaksiler protrusi bertujuan untuk mengurangi kecembungan wajah dengan meretraksi gigi anterior atas maupun bawah. ${ }^{2}$ Tujuan ini bisa dicapai dengan pencabutan keempat gigi premolar pertama. ${ }^{3}$ 
Indikasi pencabutan gigi premolar pertama adalah untuk mengoreksi diskrepansi pada bagian anterior lengkung yang akan memberi keuntungan mekanik pada proses leveling lengkung gigi. Pencabutan gigi premolar pertama digunakan untuk koreksi proklinasi gigi anterior seperti pada maloklusi kelas I dengan protrusi bidental. ${ }^{4}$ Maloklusi Angle kelas I bimaksiler protrusi mempunyai hubungan molar normal namun rahang atas maupun bawah protrusi. ${ }^{3}$ Kelainan yang paling banyak meyertai maloklusi kelas I adalah gigi berdesakan. ${ }^{5}$ Gigi berdesakan disebabkan ketidaksesuaian ukuran gigi dan lengkung geligi. Maloklusi kelas I Angle merupakan maloklusi yang paling sering dijumpai dengan prevalensi lebih dari lima puluh persen. Tujuan perawatan maloklusi kelas I antara lain meperbaiki estetik, fungsi gigi dan rahang. Bila dilakukan pencabutan gigi di rahang bawah perlu dilakukan pencabutan gigi yang sesuai di rahang atas, kecuali bila misalnya ada pergeseran midline maka pencabutan yang asimetri kemungkinan bisa dipertimbangkan. ${ }^{6}$

Teknik Begg adalah suatu metode yang dikembangkan oleh P. Raymond Begg yang dapat mengoreksi maloklusi meliputi gerakan tipping gigi. Teknik Begg mempunyai kelebihan karena keenam gigi anterior atas dan bawah ditarik secara bersamaan. Maloklusi kelas I dapat dirawat dengan teknik Begg dengan mempertahankan relasi molar tetap kelas I. Perawatan maloklusi ini pada tahap pertama menggunakan vertical loop, elastik kelas II dan anchor bend pada busur kawat. Konfigurasi ini akan menghasilkan gaya horizontal untuk meretraksi gigi-gigi anterior rahang atas untuk mengurangi overbite dan overjet yang berlebihan serta mempertahankan hubungan molar kelas I. Tahap kedua teknik Begg adalah penutupan ruang sisa pencabutan. Tahap ketiga adalah memperbaiki inklinasi aksial gigi geligi. ${ }^{7}$

Tujuan artikel ini adalah untuk memaparkan perawatan ortodontik dalam mengurangi kecembungan wajah dengan meretraksi gigi anterior atas maupun bawah, mengoreksi midline rahang atas dan bawah serta gigi berdesakan anterior dengan teknik Begg sehingga dapat memperbaiki estetik wajah

\section{STUDI KASUS}

Pasien wanita berusia 34 tahun, pekerjaan ibu rumah tangga, datang ke klinik ortodonsia FKC UGM. Hasil anamnesa diketahui pasien merasa gigigigi depan atas dan bawah maju dan berdesakan. Riwayat kesehatan tidak ada penyakit yang mempengaruhi pertumbuhan dan perkembangan gigi dan mulut. Riwayat pertumbuhan dan perkembangan gigi pada periode gigi desidui , gigi-gigi depan atas dan bawah berlubang, tidak pernah periksa ke dokter gigi. Pada periode gigi bercampur, tidak ada persistensi, gigi-gigi dirasakan mulai berdesakan sejak kelas 3 SD dan gigi depan dirasakan mulai maju sejak SMP. Pada periode gigi permanen gigi belakang bawah kanan pernah ditambal. Sekitar dua tahun yang lalu, gigi belakang atas kanan dan kiri berlubang dan telah ditambal. Tambalan tersebut lama kelamaan lepas dan tidak ditambalkan lagi, sekarang gigi-gigi tersebut tinggal akar. Dua minggu yang lalu membersihkan karang gigi ke FKG UGM. Pada riwayat keluarga, ayah pasien juga memiliki susunan gigi yang maju dan berdesakan. Pemeriksaan umum menunjukkan pasien memiliki gizi yang kurang, bentuk kepala brakisefali dan bentuk muka mesoprosop asimetris.

Pemeriksaan ekstraoral menunjukkan profil wajah cembung, tonus otot bibir normal, posisi bibir ketika istirahat terbuka. Pemeriksaan intra oral memperlihatkan kebersihan mulut sedang, ukuran lidah sedang, bentuk lengkung gigi atas dan lengkung gigi bawah parabola simetris. Susunan gigi anterior rahang atas dan rahang bawah berdesakan disertai edge to edge bite pada gigi 12 terhadap 43. Overjet $0,75 \mathrm{~mm}$ dan overbite $2,20 \mathrm{~mm}$. Hubungan gigi molar pertama kanan dan kiri Kelas I Angle. Garis tengah rahang bawah terhadap rahang atas tidak segaris, Insisivus atas bergeser ke kiri 3,25 mm dan insisivus bawah bergeser ke kanan 2,10 mm (Gambar 1 dan 2).

Berdasarkan hasil analisis sefalometri disimpulkan maloklusi skeletal kelas II dengan bimaksiler protrusi dan bidental protrusi. Analisis jaringan lunak menunjukkan bibir atas dan bawah lebih ke depan dari garis Steiner (protrusi) (Gambar 3). Diagnosis kasus pasien yaitu maloklusi Angle 

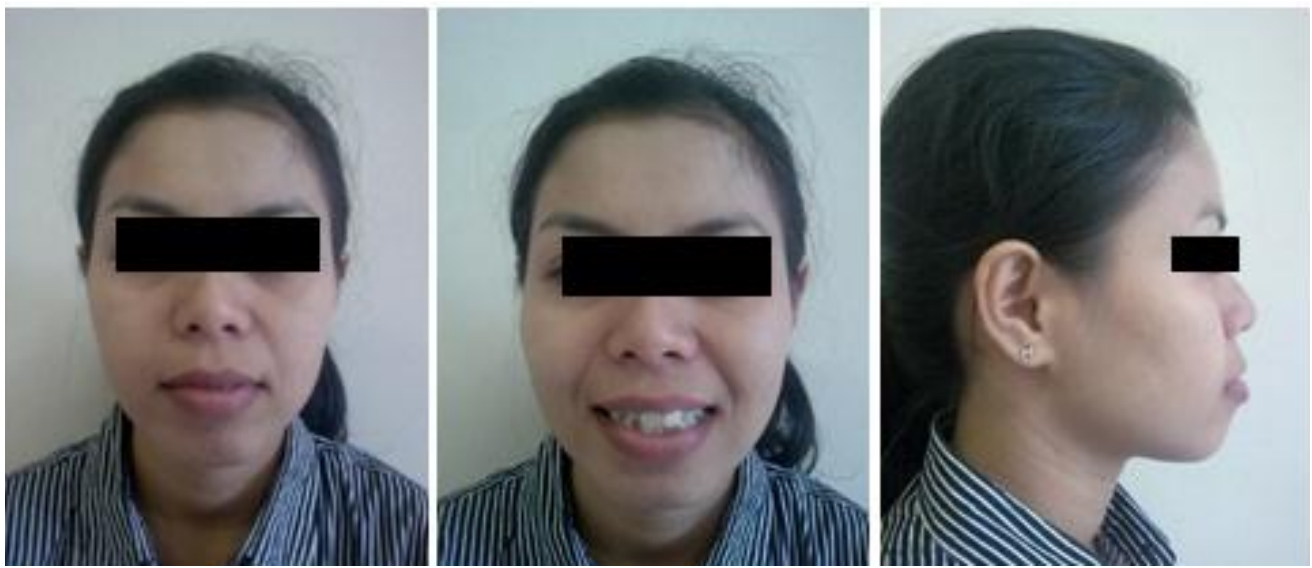

Gambar 1. Foto ekstraoral sebelum perawatan
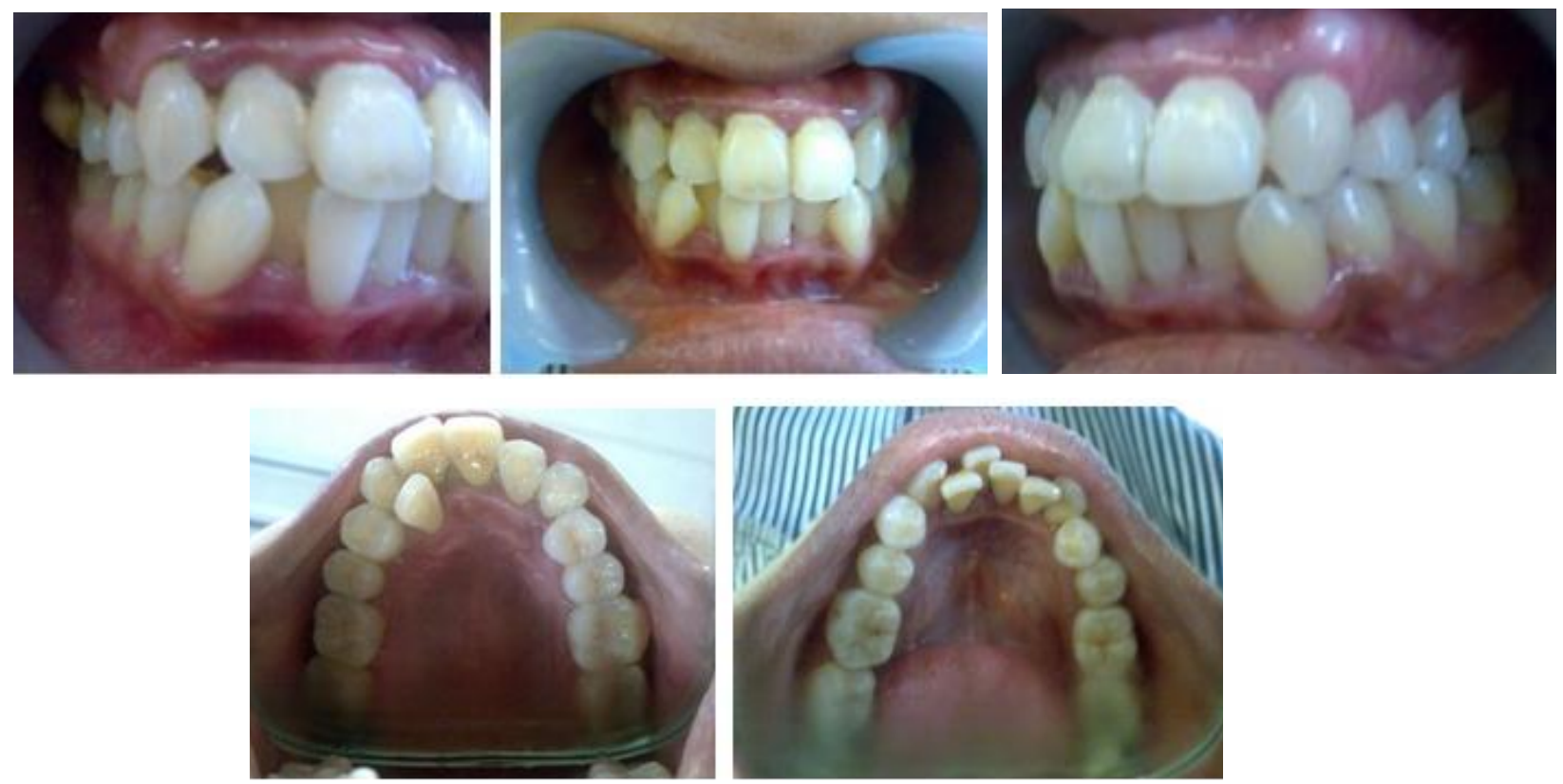

Gambar 2. Foto intraoral sebelum perawatan

kelas I, tipe skeletal kelas II dengan bimaksiler protrusi dan bidental protrusi, disertai edge to edge bite dan midline rahang atas bergeser ke kiri 3,25 mm dan RB bergeser ke kanan 2,10 mm, malrelasi dan malposisi gigi individual.

Berdasarkan perhitungan determinasi lengkung dan set up model Kesling setelah rahang atas diretraksi 3,25 mm, rahang bawah diretraksi sebesar 5,00 mm dan midline rahang atas dan rahang bawah dikoreksi, kebutuhan ruang pada rahang atas untuk kasus ini adalah sebesar 6,60 mm pada sebelah kanan dan sebelah kiri $0 \mathrm{~mm}$ (gigi 22 tidak dihitung dalam determinasi karena berada di luar lengkung), sedangkan pada rahang bawah dibutuhkan ruang sebesar 15,65 mm yaitu segmen kanan: 7,85 mm dan segmen kiri 7,80 mm. Untuk mengatasi kekurangan ruang dilakukan pencabutan gigi 14, 22 (karena berada diluar lengkung), 34 dan 44 .

Tujuan perawatan adalah mengoreksi gigi protrusi, berdesakan, edge to edge bite, ovebite dan pergeseran midline. Tahap perawatan disusun berdasarkan teknik Begg. Tujuan tahap I perawatan teknik Begg antara lain general alignment, mengatur letak gigi dengan koreksi buko-lingual (unravelling), memperbaiki ketidakteraturan dalam arah vertikal (levelling) dan koreksi relasi gigi anterior menjadi 

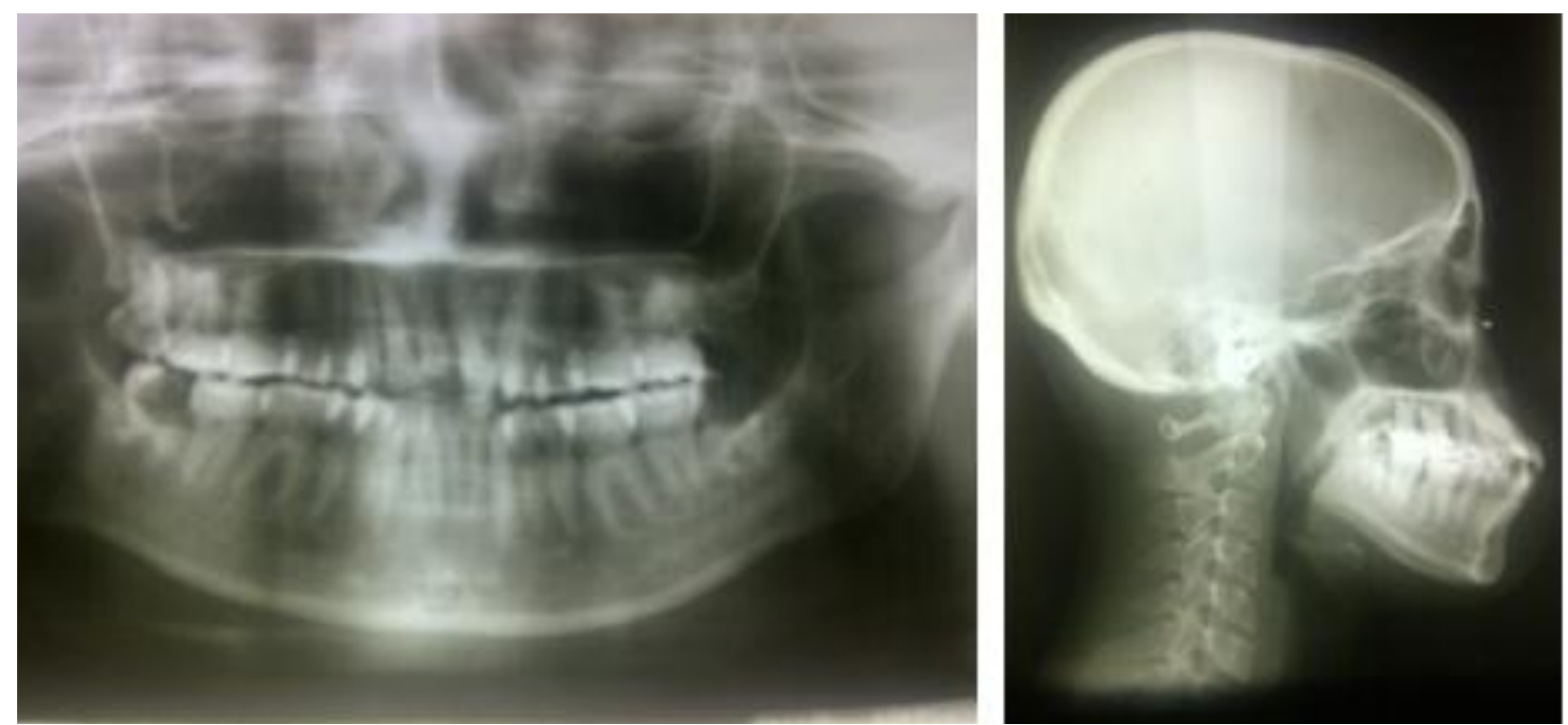

Gambar 3. Rontgen OPG dan sefalogram sebelum perawatan ortodontik

edge to edge. Koreksi gigi berdesakan, protrusi, pergeseran midline dan koreksi malposisi gigi lainnya tahap I perawatan menggunakan multiple vertical loop archwire.

Perawatan dimulai dengan menggunakan busur australian wire diameter 0,014”. Gigi rahang atas dan rahang bawah dilakukan levelling dan unravelling dengan vertical loop archwire antara gigi 12-11,11-21, 21-22, 22-23, 43-42, 42-41, 41-31, 31-32, 32-33 dan dilengkapi dengan circle hook di mesial gigi kaninus rahang atas dan rahang bawah. Pada saat insersi alat ortodontik dengan teknik Begg dilakukan by pass pada gigi 15, 25, 35 dan 45 . Pada archwire rahang atas ataupun rahang bawah dibuat anchor bend sebesar $15^{\circ}$ di mesial gigi molar pertama. Pemakaian karet elastik intermaksiler 5/16" 2 oz yang diganti setiap hari, mulai digunakan sejak tahap I. Kekuatan karet elastik tersebut mengaktifkan vertical loop arch wire pada gigi anterior yang malposisi sehingga terjadi general alignment. Setelah akhir tahap I tercapai general alignment, dilakukan retraksi gigi anterior rahang atas dan rahang bawah menggunakan plain archwire 0,016" yang dilengkapi dengan circle hook pada mesial kaninus. Hal tersebut diikuti dengan koreksi malposisi gigi dengan menggunakan rotating / uprighting auxillary spring.

Tahap II perawatan teknik Begg dilakukan space closing dengan plain archwire 0,018" dilengkapi anchor bend $15^{\circ}$ pada mesial molar pertama, circle hook pada mesial kaninus dan pemakaian karet elastik intramaksiller kelas II untuk mempertahankan relasi insisivus edge to edge.

Tahap III perawatan teknik Begg dilakukan untuk memperbaiki inklinasi aksial (root paralelling) gigi rahang atas dan rahang bawah menggunakan plain archwire 0,020" dengan anchor bend $15^{\circ}$ di mesial molar pertama, circle hook pada mesial braket kaninus, uprighting spring untuk koreksi gigi yang tilting, palatal/ lingual root torque untuk root paralleling gigi anterior rahang atas dan rahang bawah, serta elastik intermaksiler kelas II 5/16" $2 \mathrm{oz}$ untuk mempertahankan overbite dan overjet.

Perawatan telah dilakukan selama 2 tahun, malposisi dan malrelasi gigi individual terkoreksi, relasi molar tetap kelas I, Overjet menjadi $2,5 \mathrm{~mm}$ sedangkan overbite 2,2 $\mathrm{mm}$ (gambar 4 dan 5). Hasil perawatan yang telah dicapai, terlihat melalui sefalogram, FIS menjadi 124,5, IMPA 85,5 $5^{\circ}$, dan sudut interinsisal $123^{\circ}$ (Gambar 6). 


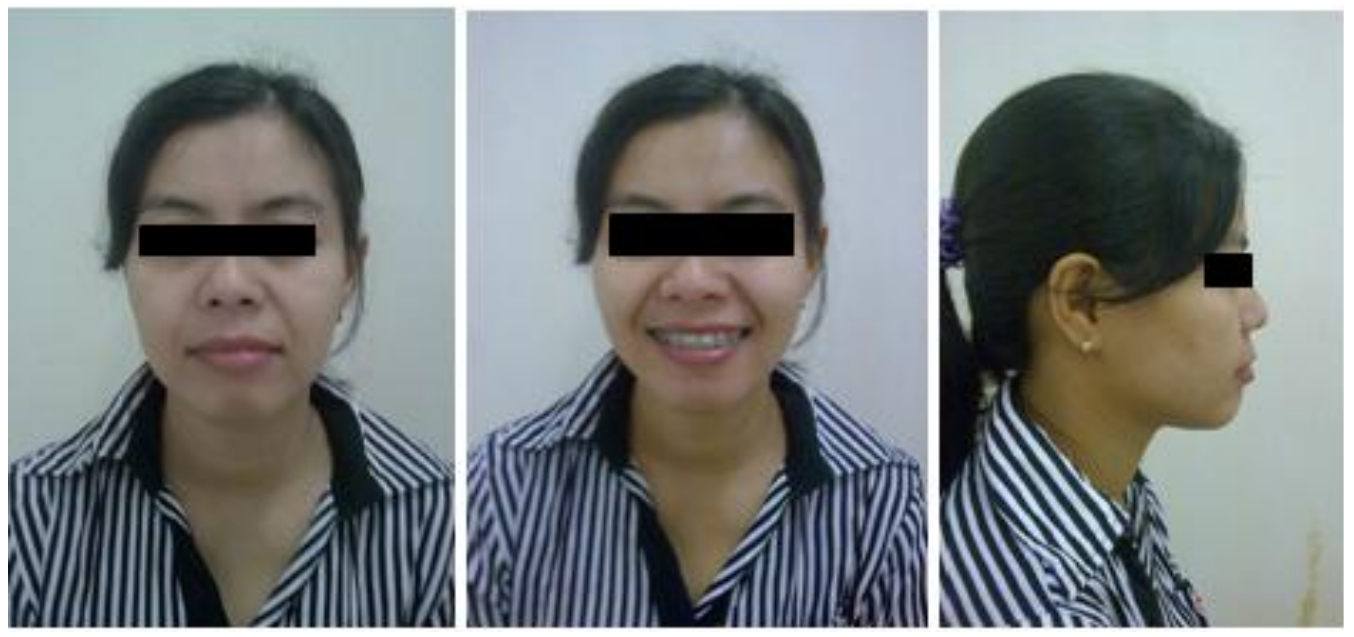

Gambar 4. Foto ekstraoral setelah 2 tahun perawatan
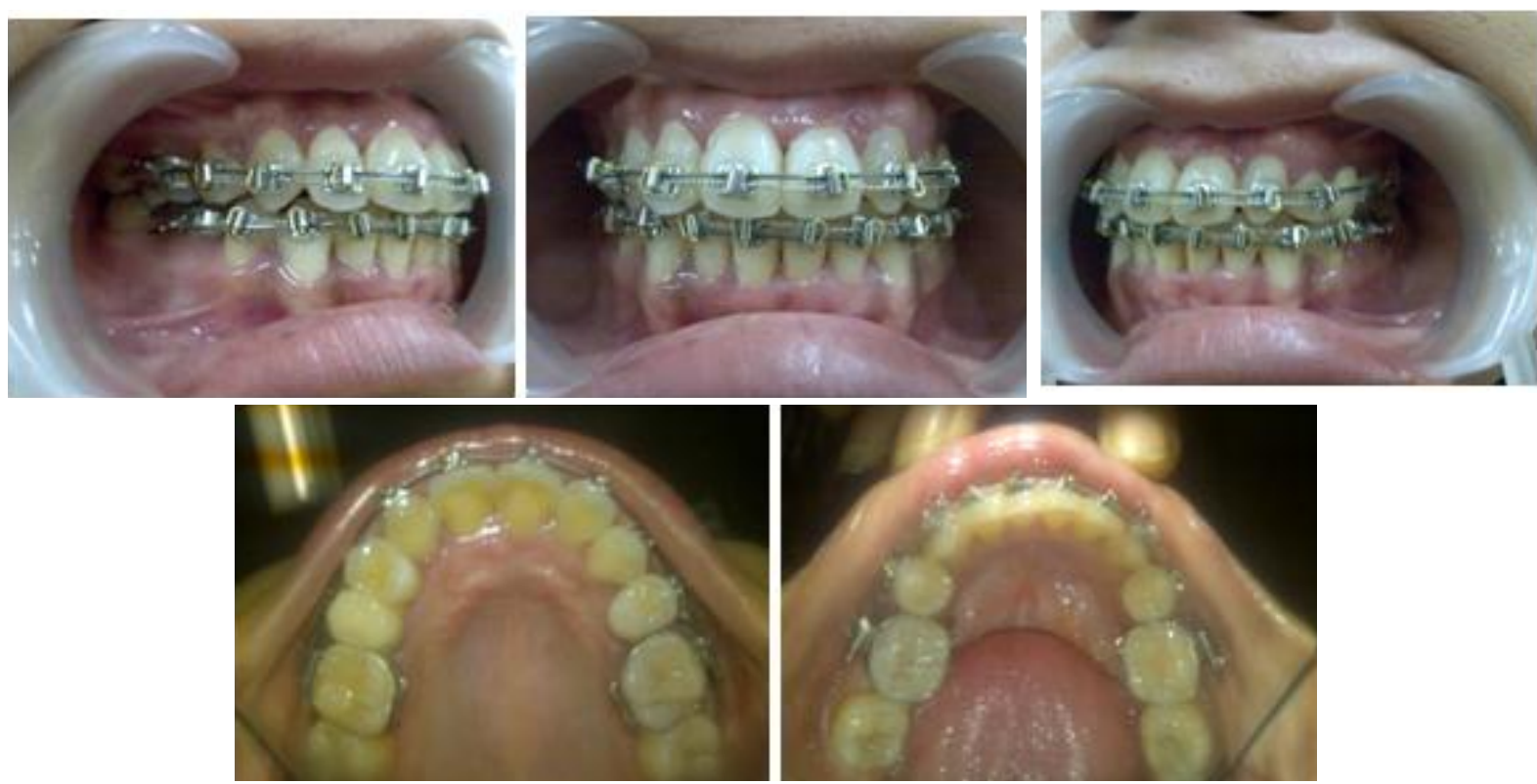

Gambar 5. Foto intraoral setelah 2 tahun perawatan
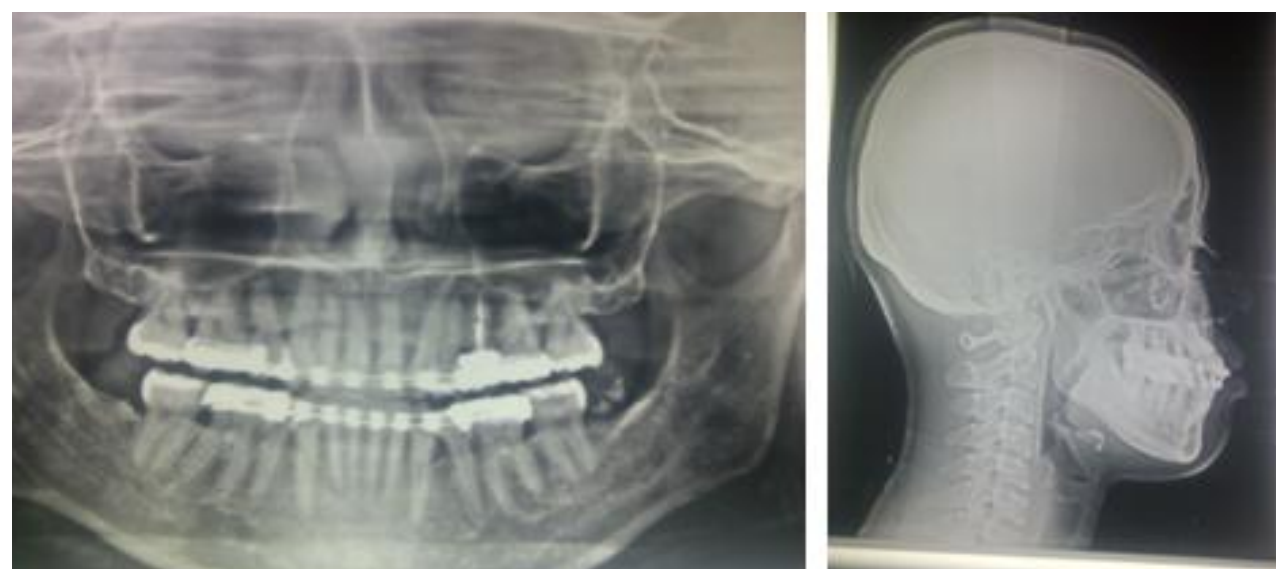

Gambar 6. Rontgen OPG dan sefalogram setelah 2 tahun perawatan ortodontik 
Tabel 1.Pengukuran sefalometri sebelum dan sesudah perawatan selama 2 tahun

\begin{tabular}{lccc}
\hline \multicolumn{1}{c}{ Pengukuran } & Nilai Normal & Sebelum Perawatan & Selama Perawatan \\
\hline Facial angle & $82^{\circ}-95^{\circ}$ & $90^{\circ}$ & $85^{\circ}$ \\
Angle of convexity & $-8,5^{\circ}-10^{\circ}$ & $+9^{\circ}$ & $+1^{\circ}$ \\
Bidang A - B & $-9-0^{\circ}$ & $-5^{\circ}$ & $-8^{\circ}$ \\
FMPA & $17^{\circ}-28^{\circ}$ & $28^{\circ}$ & $25^{\circ}$ \\
Y axis & $53^{\circ}-66^{\circ}$ & $59^{\circ}$ & $61^{\circ}$ \\
SNA & $82^{\circ}$ & $87^{\circ}$ & $82^{\circ}$ \\
SNB & $80^{\circ}$ & $82^{\circ}$ & $80^{\circ}$ \\
ANB & $2^{\circ}$ & $5^{\circ}$ & $2^{\circ}$ \\
Go.Gn-SN & $32^{\circ}$ & $35^{\circ}$ & $33^{\circ}$ \\
Inter I - I & $130^{\circ}$ & $106,5^{\circ}$ & $123^{\circ}$ \\
Sudut I - NA & $22^{\circ}$ & $36^{\circ}$ & $30^{\circ}$ \\
I- NA (mm) & $4 \mathrm{~mm}$ & $8 \mathrm{~mm}$ & $3 \mathrm{~mm}$ \\
Sudut I - NB & $25^{\circ}$ & $33^{\circ}$ & $30^{\circ}$ \\
I - NB (mm) & $4 \mathrm{~mm}$ & $11,5 \mathrm{~mm}$ & $3 \mathrm{~mm}$ \\
IMPA & $81,5^{\circ}-97^{\circ}$ & $94,5^{\circ}$ & $85,5^{\circ}$ \\
Occl PI - SN & $14^{\circ}$ & $14^{\circ}$ & $15^{\circ}$ \\
Occl PI - FHP & $1,5^{\circ}-14,3^{\circ}$ & $7^{\circ}$ & $9^{\circ}$ \\
FIS & $105-115$ & $131^{\circ}$ & $124,5^{\circ}$ \\
Overbite & $2-4 \mathrm{~mm}$ & $2,20 \mathrm{~mm}$ & $1,2 \mathrm{~mm}$ \\
Overjet & $2-4 \mathrm{~mm}$ & $0,75 \mathrm{~mm}$ & $2,5 \mathrm{~mm}$ \\
\hline
\end{tabular}

\section{PEMBAHASAN}

Kasus maloklusi Angle kelas I, hubungan skeletal kelas II dengan bimaksiler protrusi, insisivus atas dan bawah protrusi, pergeseran midline rahang atas dan bawah, overjet $0,75 \mathrm{~mm}$, disertai edge to edge bite gigi 12 terhadap gigi 43 telah dirawat selama 2 tahun. Pada kasus ini maloklusi disebabkan oleh faktor keturunan, diketahui dari hasil anamnesis ayah pasien yang memiliki susunan gigi rahang atas bawah yang maju dan berdesakan mirip dengan pasien. ${ }^{8}$

Koreksi malposisi dan malrelasi pada pasien dilakukan dengan alat cekat teknik Begg yang terdiri dari tiga tahap. Tahap pertama adalah koreksi overjet edge to edge, gigi berdesakan dan asimetri midline. Kawat yang digunakan australian wire berdiameter 0,014 ", setelah dilakukan pencabutan empat gigi. Dilakukan levelling dan unravelling dengan vertical loop archwire di antara gigi 12-11,11-21, 21-22, 22-23, 43-42, 42-41, 41-31, 31-32 dan 32-33 yang dilengkapi dengan circle hook di mesial gigi kaninus rahang atas dan rahang bawah. Circle hook dibuat simetris kanan dan kiri sehingga pada tahap ini midline bisa terkoreksi. Elastik yang digunakan adalah elastik kelas II ukuran 5/16" 2 oz. Tahap kedua penutupan ruang bekas pencabutan, Kawat yang digunakan adalah plain archwire diameter 0,018 " dengan circle hook tepat pada mesial braket gigi kaninus. Anchor bend yang digunakan sebesar $15^{\circ}$. Mesialisasi gigi posterior dilakukan dengan cara ligasi gigi anterior sebagai reverse anchorage untuk menarik gigi posterior ke depan satu per satu sehingga terjadi hubungan gigi molar yang baik. Elastik intramaksiler yang digunakan ukuran $1 / 4 ” 4 \mathrm{oz}$. Tahap ketiga adalah root paralleling. Kawat yang digunakan plain archwire ukuran 0,020" dengan circle hook tepat di mesial braket gigi kaninus serta anchor bend sebesar $15^{\circ}$ untuk stabilisasi. Lingual root torque dan palatal root torque digunakan untuk menghasilkan overjet sesuai rencana perawatan sebesar $2,5 \mathrm{~mm}$. Cinch back digunakan untuk mempertahankan lengkung gigi. Elastik intermaksiler yang digunakan pada 
perawatan tahap III adalah elastik intermaksiler kelas II ukuran 5/16" 2 oz. ${ }^{9}$

Hasil sefalogram dua tahun perawatan menunjukkan perubahan pada overbite dan overjet. menjadi normal. Perawatan yang sedang berlangsung saat ini adalah tahap III. Hasil perawatan didapatkan overbite $2,20 \mathrm{~mm}$ serta overjet $2,50 \mathrm{~mm}$. Evaluasi sefalogram menunjukkan perubahan pada FIS menjadi $124,5^{\circ}$, IMPA $85,5^{\circ}$, dan sudut interinsisal $123^{\circ}$. (Tabel 1). Perubahan relasi anterior rahang atas dan rahang bawah terjadi karena perubahan inklinasi insisivus atas dan bawah akibat retraksi gigigigi anterior rahang atas dan bawah. ${ }^{10,11}$

\section{KESIMPULAN}

Teknik Begg dapat untuk merawat maloklusi kelas I bimaksiler protrusi dengan mempertahankan relasi molar tetap kelas I. Vertical loop pada alat cekat teknik Begg dapat digunakan untuk mengkoreksi gigi berdesakan dan pergeseran midline dengan gaya yang ringan. Hasil menunjukkan perbaikan profil wajah, malrelasi, gigi berdesakan, overjet dan overbite. Midline gigi menjadi segaris dan simetris.

\section{DAFTAR PUSTAKA}

1. Bills DA, Handelman CS, BeGole EA. Bimaxillary dentoalveolar protrusion: traits and orthodontic correction. Angle Orthod. 2005; 75: 333-9.
2. Kusnoto J, Kusnoto $\mathrm{H}$. The effect of anterior tooth retraction on lip position of orthodontically treated adult indonesians. Am J Orthod Dentofacial Orthop. 2001; 120: 304-7.

3. lyyer BS. Orthodontics, the art and science. Ed 3. New Delhi: Arya (MEDI) Publishing House; 2004. H. 63-4.

4. Leonardi R, Annunziata, Licciardello, Barbato E. Soft tissue change following the extraction of premolars in nongrowing patients with bimaxillary protrusion. Angle Orthod. 2010; 80: 211-6.

5. Raharjo P. Diagnosis ortodontik. Surabaya: Airlangga University Press; 2008. H. 62-3, 85.

6. Raharjo P. Ortodonti dasar. Surabaya: Airlangga University Press; 2009. H. 70, 96-7.

7. Begg PR, Kesling PC. Begg orthodontic theory and technique. Ed 2. Philadelphia : WB Saunders Co; 1977. H. 140-3.

8. Staley RN, Reske NT. Essentials of orthodontics. Blackwell Publishing; 2011. H. 73-4.

9. Fletcher GCT. The Begg appliance and technique. Briston: John Wright \& Sons (print) Ltd; 1981. H. 35-44.

10. Graber TM. Vanarsdall. Orthodontic Current Principles and Techniques. Ed 5. Philadelphia : WB Saunders Co; 2012. H. 59-98.

11. Jacobson A. Radiographic cephalometri. Chicago: Quintessence Publishing Co; 1995. H. 53-95. 